OPEN ACCESS

Edited by:

Judith Fraussen,

University of Hasselt, Belgium

Reviewed by:

Paolo Casali,

University of Texas Health Science

Center at San Antonio, United States

Shengli Xu,

Bioprocessing Technology Institute

(A*STAR), Singapore

*Correspondence:

Mattias N. E. Forsell

mattias.forsel/@umu.se

Specialty section:

This article was submitted to

B Cell Biology,

a section of the journal

Frontiers in Immunology

Received: 27 August 2020

Accepted: 13 November 2020

Published: 05 January 2021

Citation:

Dernstedt A, Leidig J, Holm A Kerkman PF, Mjösberg J, Ahlm C,

Henriksson J, Hultdin $M$ and

Forsell MNE (2021) Regulation

of Decay Accelerating Factor

Primes Human Germinal Center

B Cells for Phagocytosis.

Front. Immunol. 11:599647.

doi: 10.3389/fimmu.2020.599647

\section{Regulation of Decay Accelerating Factor Primes Human Germinal Center B Cells for Phagocytosis}

\author{
Andy Dernstedt ${ }^{1}$, Jana Leidig ${ }^{1}$, Anna Holm ${ }^{2}$, Priscilla F. Kerkman ${ }^{1}$, Jenny Mjösberg ${ }^{3}$, \\ Clas Ahlm ${ }^{1}$, Johan Henriksson ${ }^{4}$, Magnus Hultdin ${ }^{5}$ and Mattias N. E. Forsell ${ }^{1 *}$ \\ ${ }^{1}$ Department of Clinical Microbiology, Section of Infection and Immunology, Umeå University, Umeå, Sweden, ${ }^{2}$ Department \\ of Clinical Sciences, Division of Otorhinolaryngology, Umeå University, Umeå, Sweden, ${ }^{3}$ Center for Infectious Medicine, \\ Department of Medicine, Karolinska Institutet, Stockholm, Sweden, ${ }^{4}$ Molecular Infection Medicine Sweden, Department of \\ Molecular Biology, Umeå University, Umeå, Sweden, ${ }^{5}$ Department of Medical Biosciences, Pathology, Umeå University, \\ Umeå, Sweden
}

Germinal centers (GC) are sites for extensive B cell proliferation and homeostasis is maintained by programmed cell death. The complement regulatory protein Decay Accelerating Factor (DAF) blocks complement deposition on host cells and therefore also phagocytosis of cells. Here, we show that B cells downregulate DAF upon BCR engagement and that $T$ cell-dependent stimuli preferentially led to activation of $D A F^{10} \mathrm{~B}$ cells. Consistent with this, a majority of light and dark zone GC B cells were DAF ${ }^{\text {lo }}$ and susceptible to complement-dependent phagocytosis, as compared with DAF ${ }^{\text {hi }}$ GC B cells. We could also show that the DAFi $G C B$ cell subset had increased expression of the plasma cell marker Blimp-1. DAF expression was also modulated during B cell hematopoiesis in the human bone marrow. Collectively, our results reveal a novel role of DAF to pre-prime activated human B cells for phagocytosis prior to apoptosis.

Keywords: human B cell development, germinal center (GC), decay accelerating factor (DAF), complementmediated phagocytosis, complement regulating proteins

\section{INTRODUCTION}

High affinity memory B cells and plasma cells (PCs) have undergone two distinct selection processes; during $\mathrm{B}$ cell development in the bone marrow (1) and during $\mathrm{T}$ cell-dependent germinal center (GC) responses in secondary lymphoid organs (2-7). The GC is traditionally divided into two zones based on their histological appearance where proliferation and somatic hypermutation occur in the dark zone (DZ) and T cell dependent selection in the light zone (LZ) (8).

Both the bone marrow and GCs are sites of extensive B cell proliferation. Without BCR engagement and co-stimulatory signals from $\mathrm{CD} 4^{+} \mathrm{T}$ cells, GC B cells undergo apoptosis and die. The clearance of apoptotic cells by phagocytosis is a critical process to maintain homeostasis and to restrict development of autoimmunity or inflammation $(9,10)$. Approximately $50 \%$ of all B cells die every $6 \mathrm{~h}$ during a GC reaction $(11,12)$, and these are removed by tingible body macrophages or marginal reticular cells (13-16). It has been suggested that human GC B cells are primed for apoptosis and phagocytosis (17), but a mechanism for this priming has not been demonstrated. 
Covalent attachment of complement components to cell surfaces is an important cue for phagocytosis (18). This is facilitated by C3 convertase that facilitates attachment of $\mathrm{C} 3 \mathrm{~b}$ the cell surface. This process is regulated by a number of complement regulatory proteins that inhibit complement mediated phagocytosis or lysis of healthy cells (18). The Decay Accelerating Factor (DAF or CD55) is a glycosylphosphatidylinositol (GPI) anchored protein that inhibits C3 convertase formation, and is highly expressed on B cells (19). Nonsense mutations in the CD55 gene leads to increased deposition of C3d on T cells and severe disease (20). Another example of DAFdeficiency is paroxysmal nocturnal hemoglobinuria $(\mathrm{PNH})$ where some hematopoietic stem cells have defect anchoring of DAF to cell surfaces due to a somatic mutation that inhibits generation of the GPI anchor (21). As a consequence, downstream hematopoietic cells lack GPI anchored proteins, including DAF. DAF-deficient B cells are unswitched and mainly naïve in $\mathrm{PNH}$ patients, whereas their DAF-expressing counterparts appear normal (22). Since PNH patients lack all GPI anchored proteins on their DAF-deficient B cells, more targeted investigations of DAF expression on healthy $\mathrm{B}$ cells is required to understand if the complement regulatory protein may play a direct role in human $\mathrm{T}$ cell-dependent $\mathrm{B}$ cell responses.

Due to its critical role for inhibition of C3 convertase, we hypothesized that GC B cells regulate DAF expression to become pre-primed for phagocytosis. To test this hypothesis, we set out to investigate if regulation of DAF occurs on specific subsets of human B cells in circulation, tonsils, and in bone marrow.

\section{MATERIALS AND METHODS}

\section{Donors and Tissues}

The research was carried out according to The Code of Ethics of the World Medical Association (Declaration of Helsinki). Ethical permits were obtained from the Swedish Ethical review authority (No: 2016/53-31, 04-113M, 07-162M and 2014/233) and all samples were collected after receiving informed consent from patient or patient's guardian. Briefly, blood was collected in EDTA tubes and PBMCs were isolated using a Ficoll-Paque density gradient centrifugation. Blood from HFRS patients were collected 6-10 days after disease onset. Tonsillar cell suspensions were prepared by tissue homogenizing in RPMI-1640 medium and passed through a $70 \mu \mathrm{m}$ cell strainer. Red blood cells were lysed using BD PharmLyse lysis buffer according to manufacturer's instructions. PBMCs from healthy donors were isolated by Ficoll-Paque density gradient from buffy coats from routine blood donations at the Blood Central at Umeå University Hospital, Umeå, Sweden. All cell suspensions except bone marrow aspirates were frozen in fetal bovine serum (FBS) (Gibco) with 10\% DMSO and stored in liquid $\mathrm{N}_{2}$. Bone marrow aspirates were obtained from routine sampling at the Department of Pathology, Umeå University Hospital.

\section{Flow Cytometry}

Antibodies used are listed in Supplementary Table 1. Frozen suspensions of PBMCs and tonsils were thawed, washed, and resuspended in PBS with 2\% FBS, then stained with Fixable Viability Stain 780 (BD Biosciences), followed by antibody staining for $30 \mathrm{~min}$ at $4^{\circ} \mathrm{C}$. Intracellular staining for transcription factors was performed using the eBioscience FoxP3/Transcription Factor Staining Buffer set according to manufacturer's instruction (ThermoFisher). Cells were acquired on a BD LSRII or BD FACSAria III. Cell sorting was done on BD FACSAria III. Bone marrow samples were processed by routine diagnostic procedures and acquired on a $\mathrm{BD}$ FACSCanto II. All data were analyzed using the FlowJo v10 software.

\section{Tissue Immunofluorescence}

Tonsils were fixed for $4 \mathrm{~h}$ in PBS $+4 \%$ paraformaldehyde, then incubated overnight in $30 \%$ sucrose. Samples were embedded in OCT (HistoLab) and stored at $-80^{\circ} \mathrm{C}$. Twenty $\mu \mathrm{m}$ sections of the tissues were cut in a cryostat. The sections were blocked for $1 \mathrm{~h}$ at room temperature in PBS $+5 \%$ FBS $+0.1 \%$ Triton, then stained with antibodies against CD19, IgD, CXCR4, and DAF. Full details of antibodies are listed in Supplementary Table 2. Stained sections were imaged on a Zeiss LSM 710 confocal microscope with 405, 488, 561, and $647 \mathrm{~nm}$ laser lines, using a Plan Apochromat $20 \times$ objective. All image processing was done using the Fiji software (23).

\section{Cell Culture}

PBMCs from healthy donors were seeded at $1 \times 10^{6}$ cells $/ \mathrm{ml}$ in a 96-well plate containing RPMI-1640, L-Glutamine (Gibco), 10\% fetal bovine serum (Gibco), and $100 \mathrm{U} / \mathrm{L}$ Penicillin-Streptomycin (Gibco). Cells were then stimulated with $10 \mu \mathrm{g} / \mathrm{ml}$ goat-anti human IgM+IgG (Jackson Laboratories), $2.5 \mu \mathrm{M}$ CpG B (ODN 2006, Invivogen), $1 \mu \mathrm{g} / \mathrm{ml}$ anti-CD40 (G28.5, Abcam), $25 \mathrm{ng} / \mathrm{ml}$ IL-4 (Abcam), or $25 \mathrm{ng} / \mathrm{ml} \mathrm{IL-21} \mathrm{(Abcam).} \mathrm{All} \mathrm{incubations} \mathrm{were}$ at $37^{\circ} \mathrm{C}, 5 \% \mathrm{CO}_{2}$.

\section{Microarray}

$\mathrm{DAF}^{\text {hi }}$ and $\mathrm{DAF}^{\text {lo }} \mathrm{GC} \mathrm{B}$ cells $\left(\mathrm{CD} 19^{+} \mathrm{CD} 20^{+} \mathrm{CD}^{+} 8^{+} \mathrm{IgD}^{-}\right)$were resuspended in RLT cell lysis buffer (Qiagen) after flow cytometric sorting. Total RNA was extracted (Qiagen) and microarray was performed using Affymetrix Human Clariom D microarrays (Bioinformatics and Expression Analysis core facility at Karolinska Institutet, Huddinge, Sweden). Data were analyzed in R. First the data was RMA normalized. Next, limma was used to solve the differential expression regression problems using empirical Bayes. In all cases we regressed out donor effects $\left(\sim \mathrm{x}+\right.$ donor, where $\mathrm{x}$ is e.g. $\mathrm{DAF}^{\text {hi }}$ vs $\left.\mathrm{DAF}^{\mathrm{lo}}\right)$.

\section{RT-qPCR}

For quantification of $C D 55,5,000$ each of $\mathrm{DAF}^{\text {hi }}$ and $\mathrm{DAF}^{\text {lo }} \mathrm{GC} \mathrm{B}$ cells were resuspended in RLT buffer after FACS sorting. RNA was extracted using Qiagen RNEasy Micro Kit according to instructions. One-step RT-qPCR was performed with LightCycler 480 RNA Master Hydrolysis Probes (Roche) and commercially available $C D 55$ and $A C T B$ TaqMan primers and probes during $5 \mathrm{~min}$ at $60^{\circ} \mathrm{C}, 1 \mathrm{~min}$ at $95^{\circ} \mathrm{C}$, then $15 \mathrm{~s} 95^{\circ} \mathrm{C}$ and $1 \mathrm{~min} 60^{\circ} \mathrm{C}$ for 45 cycles. RNA was loaded in triplicates and the reaction was run on a QuantStudio 5 Real-Time PCR System 
machine. CD55 expression was normalized to ACTB expression to obtain the delta $\mathrm{Ct}$ values. For validating qPCR of AICDA, $M Y C$, and PRDM1, $50000 \mathrm{DAF}^{\text {hi }}$ and $15000 \mathrm{DAF}^{\mathrm{lo}} \mathrm{GC}$ B cells were resuspended in Lysis Buffer RA1 and RNA was extracted using NucleoSpin RNA Mini kit (Macherey-Nagel) according to instructions. One-step RT-qPCR was performed as described above using commercially available TaqMan primers and probes. $C t$ values were normalized to $A C T B$ and gene expression in $D_{A F}{ }^{\text {hi }}$ GC B cells were compared to that of DAF ${ }^{\text {lo }}$ GC B cells.

\section{Phagocytosis Assay}

Primary human macrophages were cultivated from purified PBMCs from a healthy donor. One point five million PBMCs/ well were plated in RPMI-1640 supplemented with 10\% FBS and $1 \%$ Pen-Strep on $13 \mathrm{~mm}$ circular coverslips in a 24-well plate for $2 \mathrm{~h}$. Non-adherent cells were rinsed off with PBS, and RPMI1640 supplemented as described and with additional $20 \mathrm{mM}$ Hepes and $25 \mathrm{ng} / \mathrm{ml} \mathrm{M-CSF}$ (R\&D Systems). Medium was changed every third day and the cells were allowed to differentiate for 10 days. Normal human serum was collected and pooled from six healthy donors and stored at $-80^{\circ} \mathrm{C}$ immediately after isolation. After a $1 \mathrm{~h}$ incubation of CFSElabeled sorted $\mathrm{DAF}^{\text {lo }}$ or $\mathrm{DAF}^{\text {hi }} \mathrm{GC}$ B cells with macrophages in RPMI-1640, supplemented with $10 \mu \mathrm{M} \mathrm{CaCl}_{2}$ and $10 \mu \mathrm{M} \mathrm{MgCl}_{2}$ and $10 \%$ of either thawed or heat-inactivated human serum, samples were fixed with $4 \%$ paraformaldehyde in PBS and permeabilized with $0.1 \%$ Triton $\mathrm{X}-100$, followed by staining with AlexaFluor-546 phalloidin (ThermoFisher). Phagocytosis was quantified by microscopy where phalloidin ${ }^{+}$macrophages were counted, and macrophages containing CFSE signal and phagocytic vesicles were considered as phagocytosing. A total of 200 macrophages per well were counted.

\section{Statistics}

All statistic calculations were performed using GraphPad Prism 7. For comparisons between populations within the same patient, we performed Wilcoxon matched-pairs signed rank test. For the comparisons between different groups, we used the MannWhitney test. P-values lower than 0.05 were considered as significant.

\section{Data Availability}

The microarray data is available at GEO, accession GSE153741. The $\mathrm{R}$ code is available at Github (https://github.com/ henriksson-lab/mattias-daf).

\section{RESULTS}

\section{Circulating DAF ${ }^{\mathrm{lo}} \mathrm{B}$ Cells Are Expanded During Viral Infection}

While DAF is highly expressed on circulating B cells during steady-state (19), we wanted to understand if DAF can be regulated by extrinsic factors such as infection. Therefore, we compared surface expression of DAF on B cells from healthy donors and from patients diagnosed with hantavirus infection and Hemorrhagic Fever with Renal Syndrome (HFRS) (Figures 1A, B) (24). There, we found that naïve B cells $\left(C D 27^{-} \mathrm{IgD}^{+}\right)$, unswitched memory B cells $\left(\mathrm{CD} 27^{+} \mathrm{IgD}^{+}\right)$, switched memory B cells $\left(\mathrm{CD} 27^{+} \mathrm{IgD}^{-}\right)$, and $\mathrm{CD}_{27}^{-} \mathrm{IgD}^{-} \mathrm{B}$ cells from healthy individuals all had high surface expression of DAF (Figure 1B). In comparison, we found a significant reduction of DAF expression on unswitched memory $B$ cells and a marked tendency of $\mathrm{CD}_{2} 7^{-} \mathrm{IgD}^{-}$to comprise two populations that with differential DAF expression (Figures 1B, C). Since DAF is a receptor for hantaviruses (25), we performed short- and longterm exposure of PBMCs to virus, in vitro (Supplemental Figure S1). By this experiment, we could rule out that loss of DAF-signal was directly induced by the hantavirus infection. Additional analyses of the $\mathrm{DAF}^{\mathrm{lo}} \mathrm{CD} 27^{-} \mathrm{IgD}^{-} \mathrm{B}$ cells revealed that they comprised a major population of atypical B cells, characterized by low expression of the complement receptor CD21, and high expression of the inhibitory Ig receptor-like Fcrl5 and FASreceptor CD95 during HFRS (Figure 1D). We did not observe a comparably strong phenotype on $\mathrm{CD}_{2} 7^{-} \mathrm{IgD}^{-} \mathrm{B}$ cells from healthy individuals. Since DAF was downregulated on activated B cells, we hypothesized that marked regulation of DAF may also occur in secondary lymphoid organs.

\section{Specific Downregulation of Decay Accelerating Factor on Human Germinal Center B Cells}

To assess if downregulation of DAF occurs in lymphoid tissues, we performed a direct comparison of DAF expression between $\mathrm{B}$ cell subsets in circulation and in tonsils. There, we found that the frequency of $\mathrm{DAF}^{\text {hi }} \mathrm{B}$ cells was reduced on all subsets in tonsils as compared to blood but that this reduction was most prominent in the two tonsillar $\mathrm{IgD}^{-}$subsets (Figures 2A-C). We also found

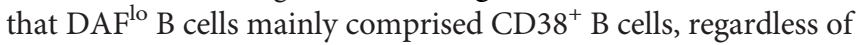
subset (Supplemental Figure S2).

By staining the cryosections of corresponding tonsils, we could demonstrate that DAF expression was high throughout non-reactive B cell follicles (Figure 2D). In contrast, DAF was downregulated in reactive follicles, where a majority of $\mathrm{B}$ cells had low or non-detectable expression of $\operatorname{IgD}$ (Figure 2E). The presence of CXCR4 staining in the reactive follicle demonstrated the presence of a GC dark zone and while we found some overlap, DAF expression appeared to locate mainly in CXCR4 ${ }^{-}$ areas. In contrast, B cells in the non-reactive follicle did not express CXCR4 and had a relatively uniform expression of DAF throughout the section, which could not be explained as unspecific binding (Supplemental Figure S3). This suggested that DAF was specifically downregulated in GC B cells. Therefore, we analyzed DAF expression by flow cytometry on tonsillar cells. Here, we could confirm that GC B cells had decreased expression of DAF compared to the other populations (Figures 2F, G).

By measurement of the cell cycle activity protein Ki67 and the transferrin receptor CD71, we found that both $\mathrm{DAF}^{\text {hi }}$ and $\mathrm{DAF}^{\text {lo }}$ GC B cells demonstrated a comparably high level of activation in contrast to resting, unswitched or switched memory B cells (Figures $\mathbf{2 H}, \mathbf{I}$ ). We could also identify that $\mathrm{DAF}^{\text {hi }} \mathrm{GC}$ B cells 

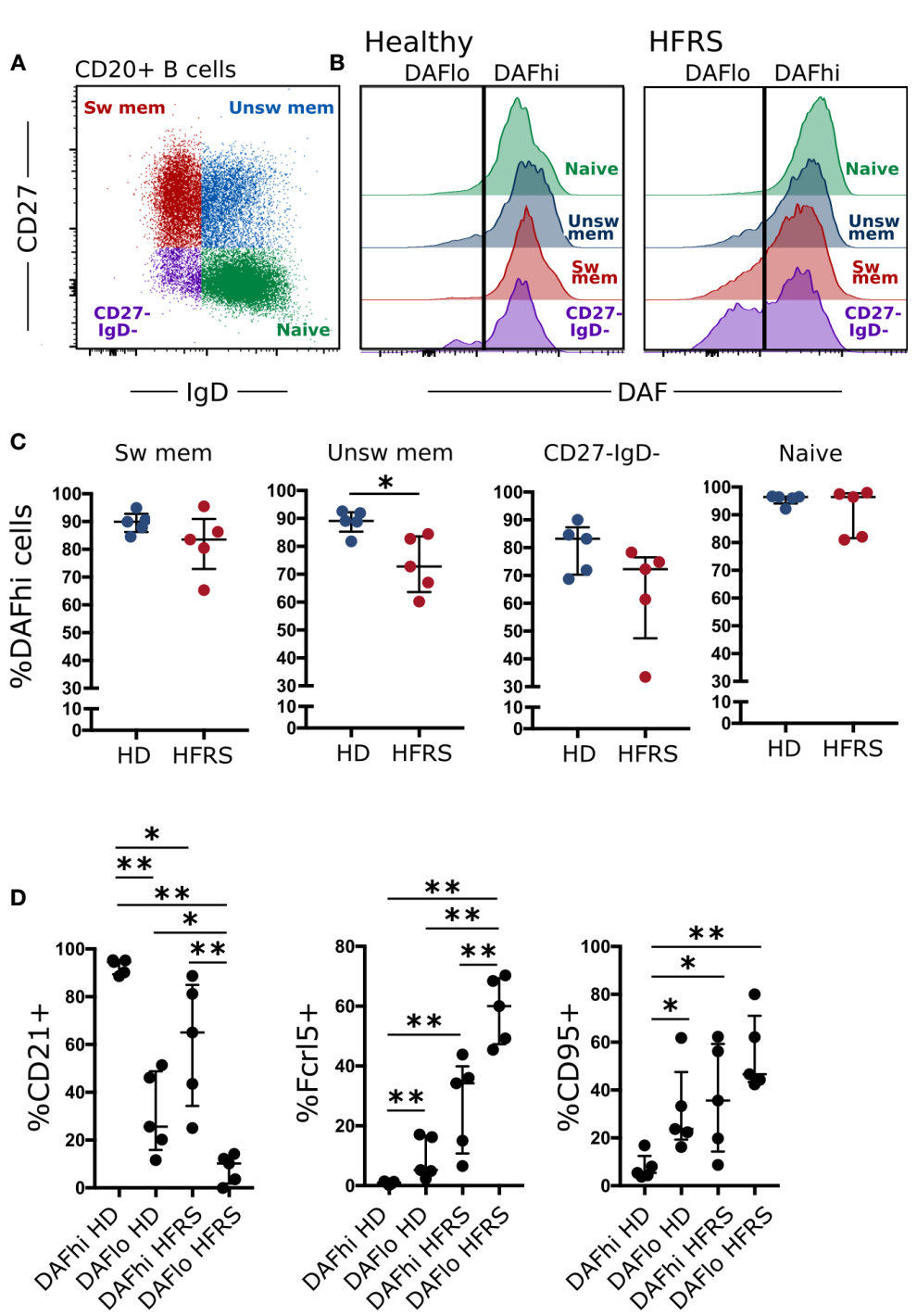

FIGURE 1 | DAF expression on circulating B cells is decreased during virus infection. (A) Flow cytometric gating to discriminate Naiive $\left(C^{-12} 27^{-} \operatorname{lgD}{ }^{+}\right)$, unswitched memory (unsw mem, $C D 27^{+} \operatorname{lgD}{ }^{+}$), switched memory (sw mem, CD27 $7^{+} \operatorname{lgD}{ }^{-}$), and CD27- IgD- CD20 $\mathrm{B}$ cells. (B) Representative histogram plots of DAF expression on B cell subsets in circulation of healthy controls (middle) or HFRS patients (right). (C) Quantification of DAF ${ }^{\text {hi }} \mathrm{B}$ cells in healthy donors or HFRS patients. ${ }^{*} \mathrm{p}<0.05$ by Wilcoxon signed-rank test. (D) Expression of CD21, Fcrl5, and CD95 in DAF hi and DAF ${ }^{\mathrm{lo}} \mathrm{CD} 27$ - IgD- B cells of HD or HFRS patients. $\mathrm{N}=5$ (healthy donors) and 5 (HFRS patients). ${ }^{*} \mathrm{P}<0.05$; ${ }^{\star \star} \mathrm{P}<0.01$ by Wilcoxon signed-rank test. Bars show median and interquartile range.

had higher expression of both CD21 (Figure 2J) and CD95 (Figure $2 \mathrm{~K}$ ) as compared with DAF ${ }^{\text {lo }}$ GC B cells. Since CD21 has been shown to reduce the threshold for BCR stimulation, and CD95 is critical for the extrinsic apoptosis pathway, this suggests that $\mathrm{DAF}^{\mathrm{lo}}$ GC $\mathrm{B}$ cells have reduced potential for BCR stimulation and are less sensitive to apoptosis than their $\mathrm{DAF}^{\text {hi }}$ counterparts $(26,27)$.

\section{Transcriptomic Profile of DAFhi and DAFlo Germinal Center B Cells}

Next, we assessed the transcriptional profile of bulk sorted DAF $\mathrm{F}^{\text {hi }}$ and DAF ${ }^{\text {lo }}$ GC B cells (Supplemental Figure S4) by a Human Clariom-D microarray. Analysis of resulting data revealed that both $\mathrm{DAF}^{\text {hi }}$ and $\mathrm{DAF}^{\text {lo }}$ GC B cells had a large number of genes that were more than two-fold differentially expressed (Figure 3A, Supplementary Table 3). Of note, DAF ${ }^{\mathrm{lo}}$ GC B cells had upregulated genes, which suggested on-going somatic hypermutation, such as BACH2, FOXO1, and AICDA (4, 2931), whereas $D A F^{\text {hi }}$ GC B cells showed elevated expression of genes involved in B cell differentiation (PRDM1, IRF4, CCR6), class switching $(B A T F)$, gene editing (APOBEC $3 B)$, and regulation of transcription (MYC) (32-37). Surprisingly, the gene encoding DAF (CD55), showed similar transcription levels between the two subsets and we could confirm this by RT-qPCR (Figure 3B). The differential expression of MYC, $A I C D A$, and PRDM1 in sorted $\mathrm{DAF}^{\mathrm{hi}}$ and $\mathrm{DAF}^{\mathrm{lo}} \mathrm{GC} \mathrm{B}$ cells 

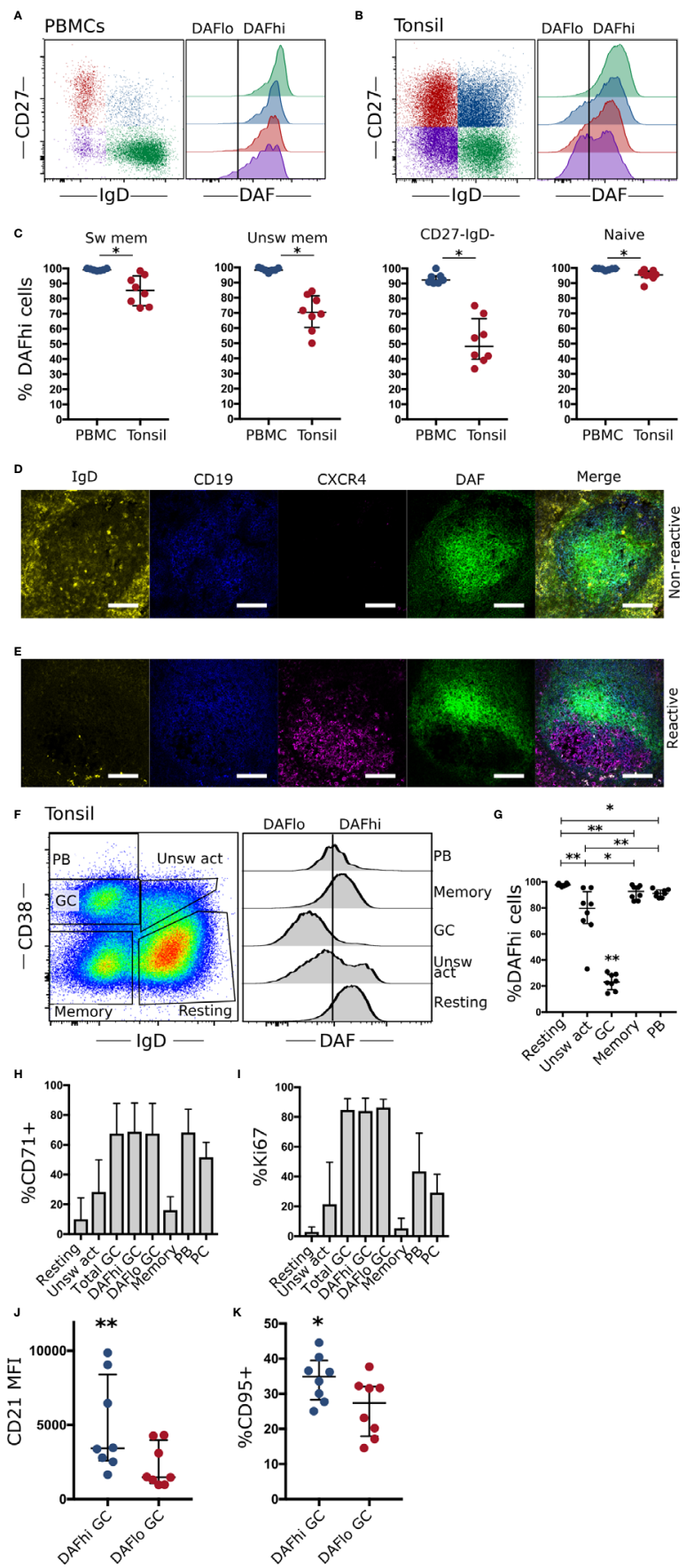

FIGURE 2 | Germinal center B cells specifically downregulate DAF. (A) Representative flow cytometric plots and quantification of DAF expression on CD19+ CD20 naïe

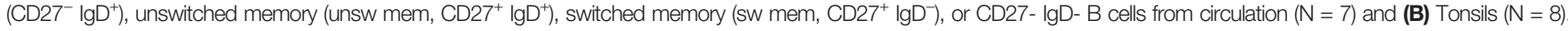
(C) Quantified \%DAFhi of indicated B cell populations. Individual dots for each sample are shown and lines indicate median with interquartile range. (D) Representative section of a non-reactive tonsillar B cell follicle stained with lgD (yellow), CD19 (blue), CXCR4 (magenta), and DAF (green). Scale bar = $100 \mu \mathrm{m}$. (E) Representative staining of reactive B cell follicle. Scale bar $=100 \mu \mathrm{m}$. (F) Representative plot for flow cytometric subset analysis of DAF expression on germinal center cells (GC, CD38 ${ }^{+}$, lgD'), naïve B cells (CD38

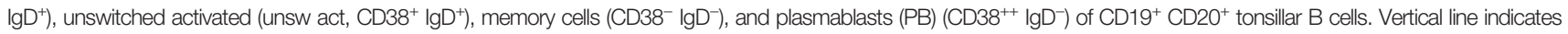
the cutoff to discriminate DAF ${ }^{\text {hi from DAF }}{ }^{\mathrm{lo}}$ cells. (G) Quantification of DAF expression on tonsillar B cell subsets. Individual dots for each sample are shown and lines indicate median with interquartile range. $(\mathbf{H})$ Frequency of $\mathrm{B}$ cell subsets with high expression of the transferrin receptor CD71. Data is represented as bar graphs showing median and interquartile range. (I) Frequency of B cell subsets with high expression of Ki67. Data is represented as bar graphs showing median and interquartile range. (J) Median fluorescence intensity (MFI) of CD21 on DAF ${ }^{\text {hi }}$ and DAF $F^{\text {lo }}$ GC B cells. (K) Quantified \%CD95+ cells of DAF ${ }^{\text {hi }}$ and DAF ${ }^{\text {lo }}$ GC B cells. ${ }^{\star} P<0.05$; ${ }^{* *} P<0.01$ by Wilcoxon signedrank test. Bars show median with interquartile range. 

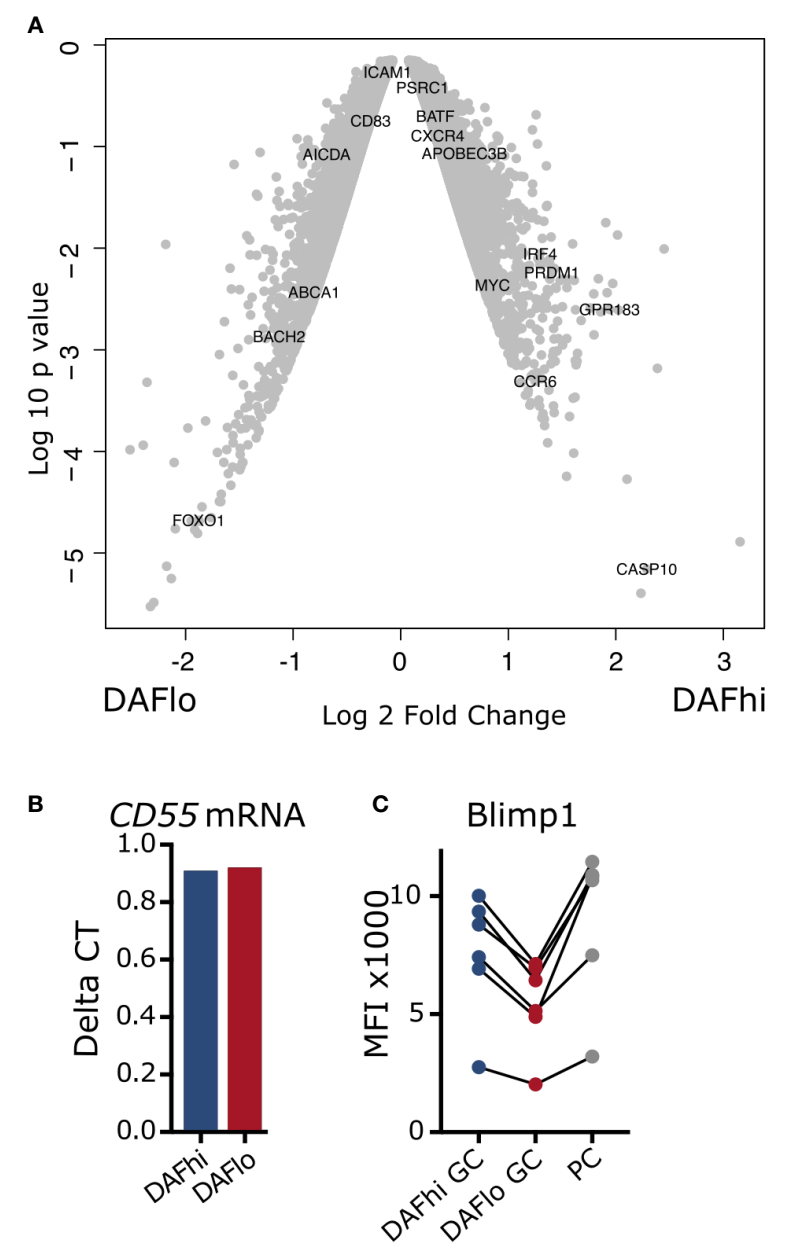

D

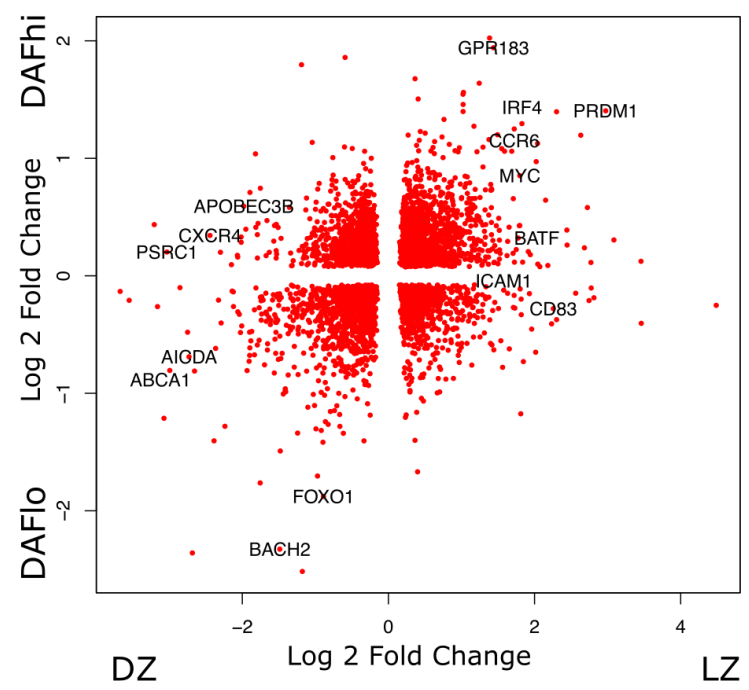

FIGURE 3 | Transcriptomic analysis of DAF $F^{\text {hi }}$ and DAF ${ }^{\text {lo }}$ germinal center $B$ cells. (A) Volcano plot showing differences in genes expressed by DAF $F^{\text {hi }}$ and DAF $F^{\text {lo }}$ GC $B$ cells. (B) Delta CT of CD55 gene expression, normalized to ACTB. (C) Flow cytometric analysis of Blimp1 expression on DAF ${ }^{\text {hi, }}$ DAF ${ }^{\text {lo }} \mathrm{GC} B$ cells, and plasma cells $(P C)(N=6)$. (D) Clustering of DAF ${ }^{\text {hi }}$ and DAF ${ }^{\text {lo }} \mathrm{GC} B$ cells in combination with transcriptomic data from sorted light zone (LZ) and dark zone (DZ) GC B cells. LZ and DZ data were obtained from Victora et al. (28). 
was verified by qPCR of bulk sorted cell subsets (Supplemental Figure S4). Consistent with $P R D M 1$ being upregulated in the $\mathrm{DAF}^{\mathrm{hi}}$ subset, we found that the gene product Blimp1 was similarly upregulated in the DAF ${ }^{\text {hi }}$ subset (Figure 3C). These

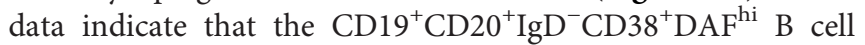
subset may comprise early GC-derived PB or PCs.

Although many of the genes upregulated in $\mathrm{DAF}^{\mathrm{lo}} \mathrm{GC} \mathrm{B}$ cells are typically associated with DZ B cells, the expression of the DZ marker CXCR4 was not increased. Instead, the LZ marker CD83 was increased in $\mathrm{DAF}^{\text {lo }} \mathrm{GC}$ B cells and the DZ marker CXCR4 was increased in DAF ${ }^{\text {hi }}$ GC B cells (Figure 3A). This indicated that both the $\mathrm{LZ}$ and DZ comprise DAF ${ }^{\mathrm{hi}}$ and $\mathrm{DAF}^{\mathrm{lo}} \mathrm{B}$ cells. Therefore, we combined our transcriptional analysis of $\mathrm{DAF}^{\text {hi }}$ and $\mathrm{DAF}^{\text {lo }} \mathrm{GC} \mathrm{B}$ cells with published data on sorted LZ and DZ B cells (28). Through this analysis, we found transcriptional patterns that applied to both $\mathrm{DZ}$ and LZ from sorted DAF ${ }^{\text {hi }}$ and DAF ${ }^{\text {lo }}$ GC B cells (Figure 3D). However, and consistent with our other data, the clustering suggested that $\mathrm{DAF}^{\mathrm{lo}} \mathrm{B}$ cells in the $\mathrm{DZ}$ are proliferating and undergoing SHM, whereas $\mathrm{DAF}^{\mathrm{hi}} \mathrm{B}$ cells contained a transcriptional profile indicative of final differentiation in the LZ.

\section{Decay Accelerating Factor Expression in Dark Zone and Light Zone of Germinal Centers}

Next, we used expression of CXCR4 and CD83 to analyze DAF expression on GC B cells in DZ and LZ, respectively (Figure 4A). Consistent with our transcriptional analysis, we found $D A F^{\text {hi }}$ and $\mathrm{DAF}^{\mathrm{lo}}$ populations in both zones, where the frequency of $\mathrm{DAF}^{\text {hi }}$ cells was slightly decreased in the LZ (Figure 4B). It is established that B cells undergo apoptosis rather than lysis in GCs (38). We therefore assessed expression of the complement regulatory protein CD59 that inhibits formation of the membrane attack complex, and of complement receptors CD35 and CD21, which are involved in both complement regulation, and $\mathrm{B}$ cell activation. We found that CD59, CD35, and CD21 were expressed at similar levels regardless of zonal location or DAF phenotype, although we observed a trend of higher expression of CD35 and CD21 on DAF ${ }^{\text {hi }}$ cells in both zones (Figure 4C). We could also confirm that GC B cells had increased expression of CD59, as compared to non-GC B cell subsets, excluding $\mathrm{PBs}$ and PCs (Figure 4D). In addition, the negative complement regulator CD46 (Figure 4E), which inactivates $\mathrm{C} 4 \mathrm{~b}$ and $\mathrm{C} 3 \mathrm{~b}$, and the complement receptor $1, \mathrm{CD} 35$ (Figure 4F), were also reduced in $\mathrm{DAF}^{\text {lo }} \mathrm{GC}$ B cells. The low expression of DAF and CD46 on a majority of GC B cells indicated that these cells can accumulate complement on their surface, and the high expression of CD59 demonstrated that the complement cascade was inhibited prior to formation of the membrane attack complex. Our data therefore suggested that $\mathrm{DAF}^{\text {lo }}$ GC B cells may be sensitive to complement-dependent phagocytosis.

\section{B Cell Receptor Stimulation Leads to Downregulation of Decay Accelerating Factor Expression}

Although downregulation of DAF was most pronounced on GC $B$ cells, DAF was also reduced on a fraction of unswitched activated $\left(\mathrm{CD}^{2} 8^{+} \mathrm{IgD}^{-}\right) \mathrm{B}$ cells in tonsils (Figure 2F). Hence, it was possible that BCR-stimulation alone or in concert with costimulatory factors could directly regulate DAF expression. To assess $\mathrm{T}$ cell-independent activation of $\mathrm{B}$ cells, we stimulated PBMCs from healthy donors with anti-IgM/IgG with or without CpG for 4 days (Figure 5A). We found that BCR-stimulation alone led to a reduction of $\mathrm{DAF}^{\mathrm{hi}} \mathrm{B}$ cells and that co-stimulation with $\mathrm{CpG}$ enhanced this reduction (Figure 5B). In contrast, $\mathrm{CpG}$ alone had no effect on the frequency of DAF ${ }^{\text {hi }} \mathrm{B}$ cells. We proceeded to assess if $\mathrm{T}$ cell-dependent activation was similarly effective to enhance BCR-induced downregulation of DAF by coincubating with anti-CD40, and recombinant IL-4 or IL-21, respectively (Figure 5C). Of these, IL-21 had a minor but significant effect on the frequency of $\mathrm{DAF}^{\text {hi }} \mathrm{B}$ cells in the presence of anti-IgM/IgG (Figure 5D). These data demonstrated that DAF expression is regulated via BCRstimulation, and that selected co-stimulatory factors during both $\mathrm{T}$ cell-dependent and $\mathrm{T}$ cell-independent activation of $\mathrm{B}$ cells enhanced the number of $\mathrm{DAF}^{\mathrm{lo}}$ cells. Throughout all conditions used for $\mathrm{T}$ cell-dependent and independent stimulation of B cells, we consistently found that Blimp-1 was expressed at a higher level on $\mathrm{DAF}^{\text {hi }}$ than on $\mathrm{DAF}^{\text {lo }} \mathrm{B}$ cells (Figure 5E). These data support our findings that $\mathrm{DAF}^{\mathrm{hi}} \mathrm{GC} B$ cells comprise a subpopulation of early GC-derived $\mathrm{PB} / \mathrm{PC}$. However, $\mathrm{T}$ cell-independent stimulation induced high level of Ki67 expression in both $\mathrm{DAF}^{\text {hi }}$ and $\mathrm{DAF}^{\mathrm{lo}} \mathrm{B}$ cells but $\mathrm{T}$ celldependent stimulation preferentially led to activation of $\mathrm{DAF}^{\text {lo }} \mathrm{B}$ cells (Figure 5F). This demonstrated that the nature of costimulatory signals govern the activation state of $\mathrm{DAF}^{\text {hi }}$ or $\mathrm{DAF}^{\mathrm{lo}} \mathrm{B}$ cells, respectively.

\section{Phagocytosis of DAF ${ }^{10}$ Germinal Center B Cells Is Enhanced in the Presence of Complement}

A previous study demonstrated that DAF-deficient human $\mathrm{T}$ cells accumulate C3d on their cell surfaces in vitro (20), and that this can facilitate phagocytosis (39). Therefore, we hypothesized that $\mathrm{DAF}^{\text {lo }}$ GC B cells would be more efficiently phagocytosed than their DAF ${ }^{\text {hi }}$ counterparts, in a complement-dependent manner. To test this hypothesis, we sorted CFSE-labeled DAF ${ }^{\text {hi }}$ and DAF $^{\text {lo }}$ GC B cells and co-cultivated these with primary human macrophages in the presence of human serum prior or after heat inactivation of complement. Phagocytosis of B cells was then assessed by counting Phalloidin ${ }^{+}$macrophages that had internalized vesicles that contained the CFSE dye from the sorted B cells (Figure 5G). Consistent with our hypothesis, we could show efficient and complement-dependent phagocytosis of $\mathrm{DAF}^{\text {lo }} \mathrm{GC} \mathrm{B}$ cells, in comparison with DAF ${ }^{\text {hi }}$ GC B cells (Figure 5H). Together, these observations strongly suggest that GC B cells are pre-primed for complement-dependent phagocytosis, and that this is regulated by a reduction of DAF on their cell surface.

\section{Modulation of Decay Acclerating Factor Expression During B Cell Hematopoiesis in the Bone Marrow}

Similar to GC structures in secondary lymphoid organs, the bone marrow represents another site of extensive B cell proliferation. 

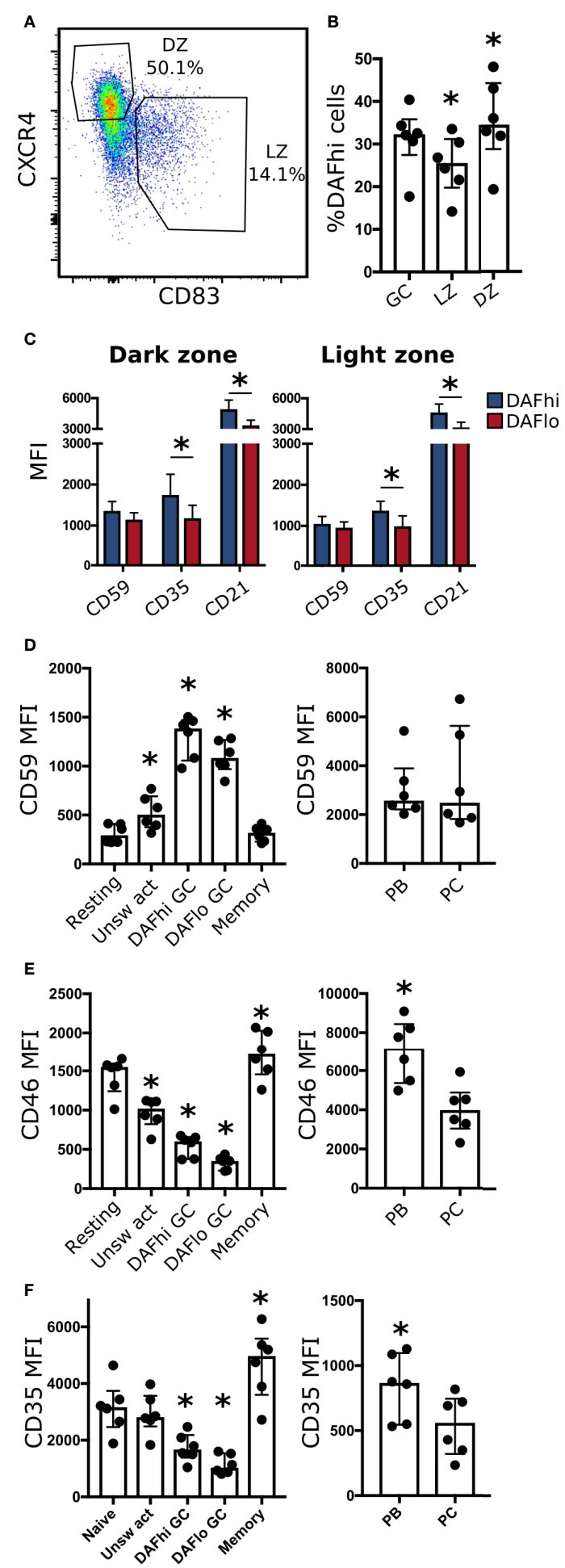

FIGURE 4 | DAF expression on DZ and LZ B cells. (A) Representative gating strategy for light zone (LZ, CD83 $\left.{ }^{+} \mathrm{CXCR} 4^{-}\right)$and dark zone (DZ, CD83 $\left.{ }^{-} \mathrm{CXCR} 4^{+}\right)$of $\mathrm{CD}_{19}{ }^{+} \mathrm{CD} 2 \mathrm{O}^{+} \mathrm{CD}^{2} 8^{+} \mathrm{IgD}{ }^{-} \mathrm{B}$ cells. (B) Frequency of DAF ${ }^{\text {hi }}$ cells within the total GC B cell population and on $\mathrm{LZ}$ and DZ GC B cells. Bars represent median with interquartile range. ${ }^{*} \mathrm{P}<0,05$ by Wilcoxon signed-rank test. (C) Expression of CD59, CD35, and CD21 on DAF ${ }^{\text {hi }}$ or DAF ${ }^{\text {lo }} \mathrm{GC} B$ cells in DZ (left) or LZ (right). (D) Expression of CD59, (E) CD46, and (F) CD35 on resting, unswitched activated (Unsw act), DAF ${ }^{\text {hi }}$ or DAF ${ }^{\mathrm{lo}} \mathrm{GC} B$ cells, and memory B cells (left), and plasmablasts (PB) and plasma cells (PC) (right). Median fluorescence intensity (MFI) is represented as individual dots where lines indicate median with interquartile range. Data was acquired from multiple patients $(n=6)$. Bars represent median with interquartile range. ${ }^{*} P<0.05$ by Wilcoxon signed-rank test. 

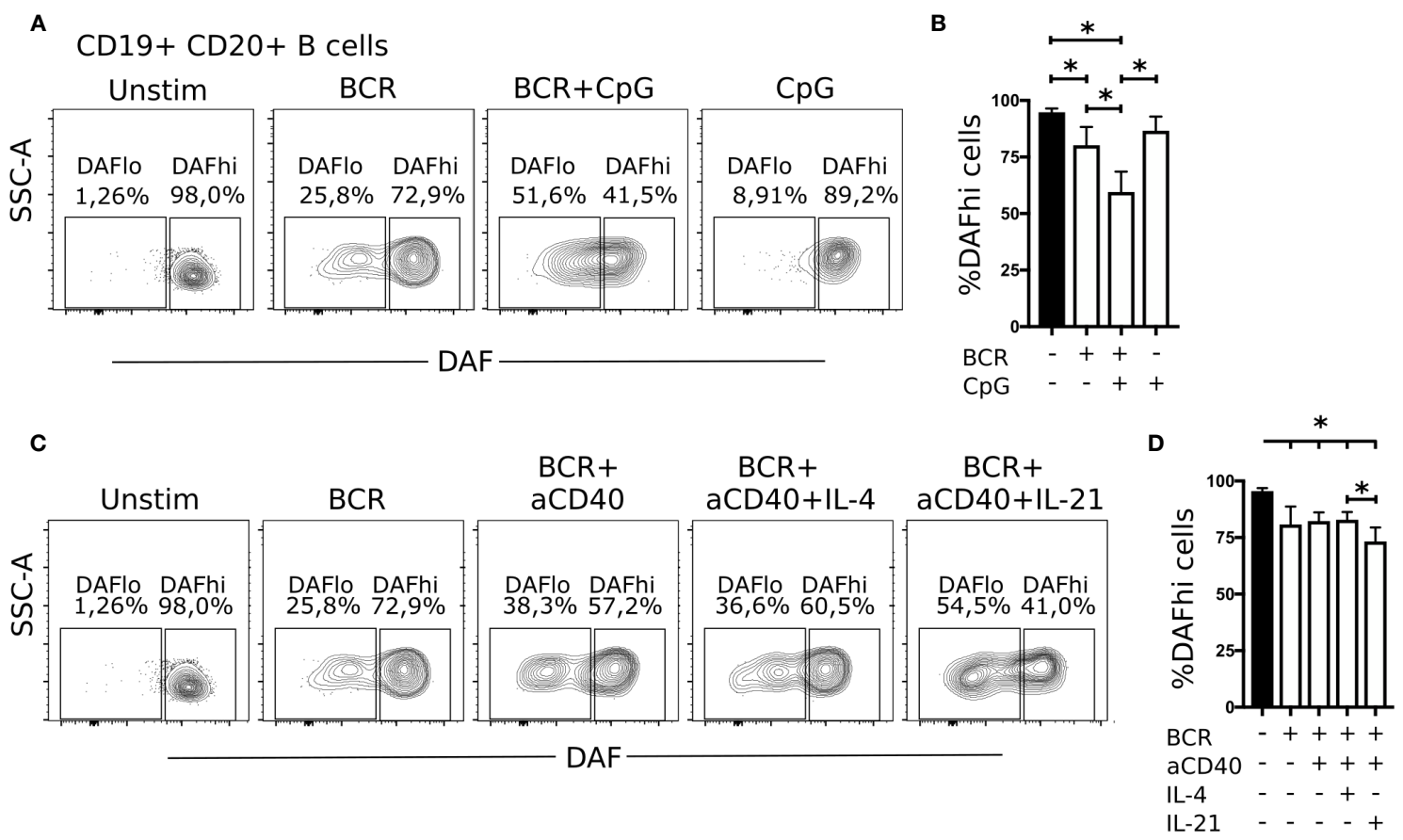

E

CD19+ CD20+ B cells

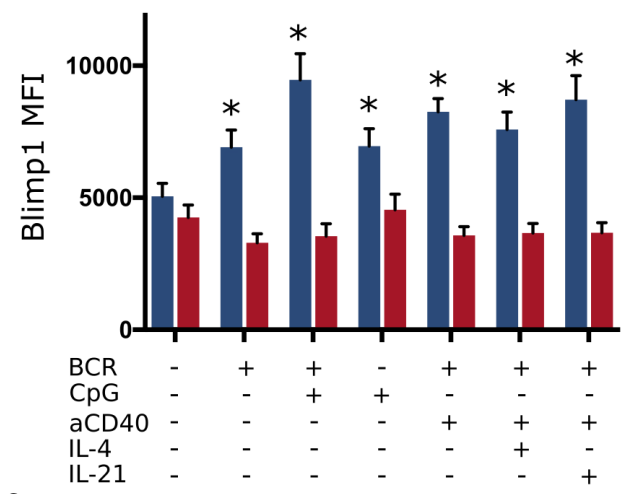

G
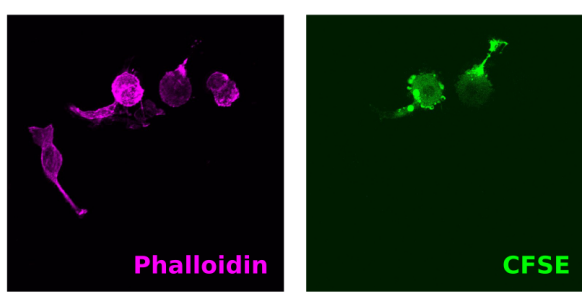

F

F CD19+ CD20+ B cells 
A

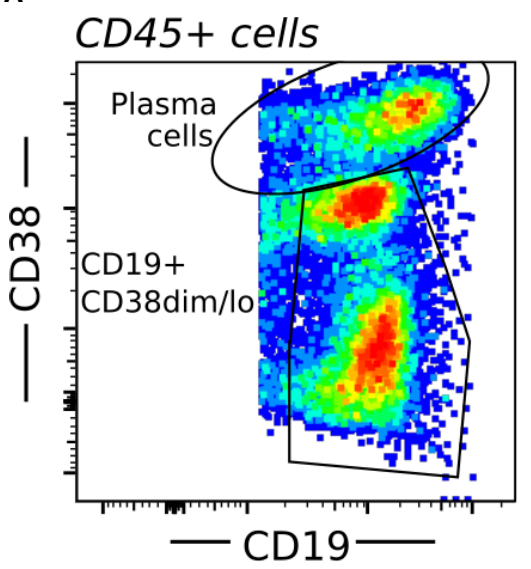

D $C D 19+C D 38 d i m / l o$ CD34-

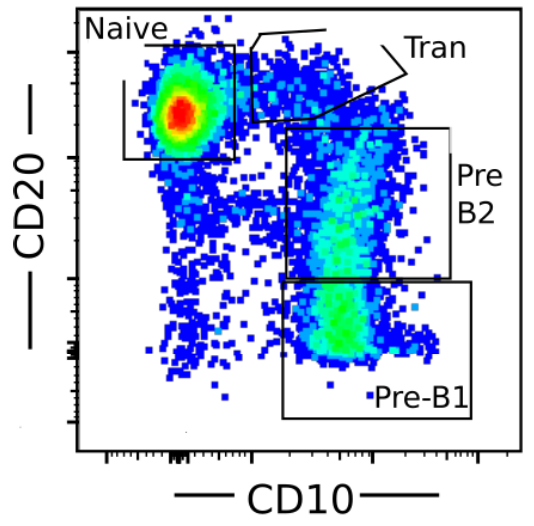

E

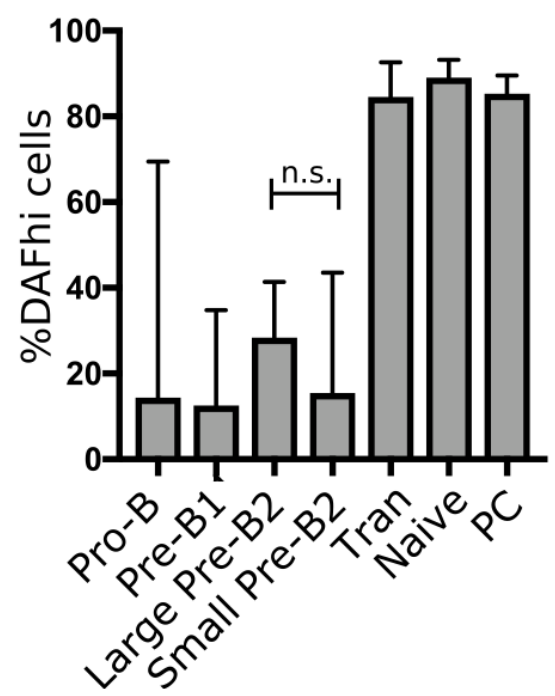

B

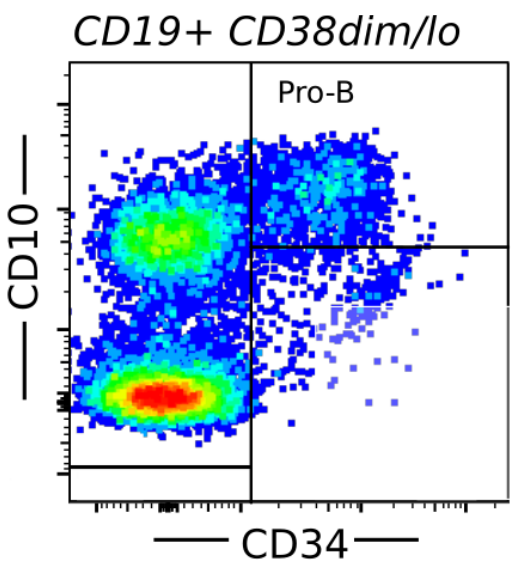

E

DAFlo DAFhi

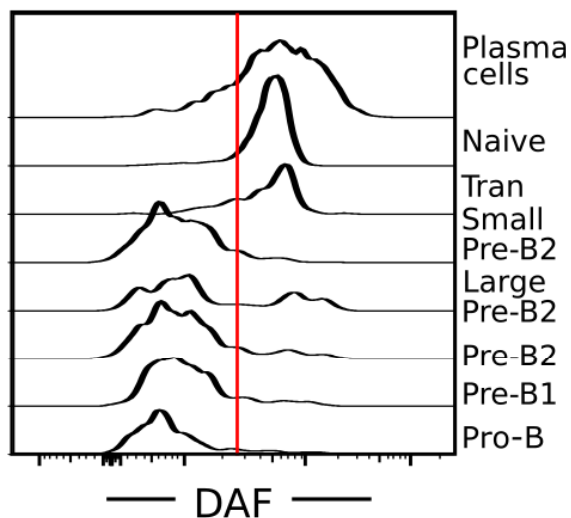

$\mathbf{F}$

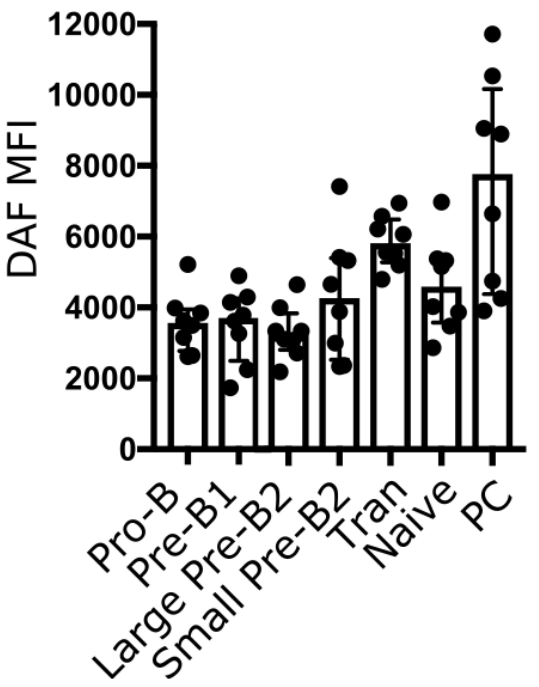

FIGURE 6 | Regulation of DAF expression during B cell hematopoiesis. (A-C) Flow cytometric analysis of human bone marrow aspirates. Shown are (A) PCs $\left(\mathrm{CD} 19^{+} \mathrm{CD} 38^{\text {hi }}\right)$ and B cells $\left(\mathrm{CD} 19^{+} \mathrm{CD} 38^{\text {dim/lo }}\right)$, (B) Pro-B cells $\left(\mathrm{CD} 34^{+} \mathrm{CD} 10^{+}\right)$, and $(\mathbf{C})$ Pre-B1 cells $\left(\mathrm{CD} 10^{+} \mathrm{CD} 20^{-}\right)$, pre-B2 cells $\left(\mathrm{CD} 10^{+} \mathrm{CD} 20^{+}\right)$, transitional B cells (Tran, $\left.\mathrm{CD} 10^{\text {dim }} \mathrm{CD}_{2} \mathrm{O}^{++}\right)$, and mature B cells $\left(\mathrm{CD} 10^{-} \mathrm{CD} 2 \mathrm{O}^{++}\right)$. (D) Representative histogram of DAF expression from respective $\mathrm{B}$ cell subset in bone marrow. The line indicates the cutoff for determination of high or low DAF expression. (E, F) Quantification of data from (D). Shown is median with interquartile range. n.s., non-significant. $\mathrm{N}=8$. 
To understand if DAF may play a role also in early B cell development, we obtained human bone marrow samples from routine biopsies and stratified the stages of B cell development by flow cytometry (40). Briefly, we separated PCs $\left(\mathrm{CD} 19^{+}\right.$CD $\left.38^{\text {hi }}\right)$ from other $\mathrm{B}$ cells and precursors $\left(\mathrm{CD} 19^{+} \mathrm{CD} 38^{\mathrm{dim} / \mathrm{lo}}\right.$ ) (Figure 6A). Pro-B cells were identified as $\mathrm{CD}^{+} 4^{+} \mathrm{CD} 10^{+}$(Figure 6B). Then, we used CD20 and CD10 identify Pre-B1 cells $\left(\mathrm{CD} 10^{+}\right.$ $\left.\mathrm{CD} 20^{-}\right)$, pre-B2 cells $\left(\mathrm{CD} 10^{+} \mathrm{CD} 20^{+}\right)$, transitional B cells $\left(\mathrm{CD} 10^{\mathrm{dim}} \mathrm{CD} 20^{++}\right)$, and naive $\mathrm{B}$ cells $\left(\mathrm{CD} 10^{-} \mathrm{CD} 20^{++}\right)$(Figure 6C). The pre-B2 subset could then be further divided into large and small cells, based on forward scatter. Subsequent assessment of DAF on the different B cell populations revealed that surface expression of DAF was low from the Pro-B stage until the large immature stage, where the expression followed a bimodal pattern (Figure 6D). Small pre-B2 cells showed uniformly low expression of DAF whereas large pre-B2 cells showed a bimodal pattern of DAF expression. From the transitional B cell subset and onward, DAF expression was uniformly high, where PCs demonstrated the highest surface expression of DAF. Both MFI and $\% \mathrm{DAF}^{\mathrm{hi}}$ cells of parent followed this pattern throughout the developmental stages (Figures 6E, F). Together, these data demonstrate that DAF is upregulated on a fraction of cells at a late developmental stage where testing of the pre-BCR or formation of a functional BCR occurs. These data demonstrate that, similar to GCs, DAF is regulated also during B cell development in the bone marrow.

\section{DISCUSSION}

The complement regulatory protein DAF is well known to inhibit complement activation on cell surfaces. Here, we demonstrate that human GC B cells downregulate DAF on their cell surfaces, and that one function of this downregulation is to prime GC B cells for complement-dependent phagocytosis.

Our transcriptional data suggest that the distribution of $\mathrm{DAF}^{\mathrm{lo}}$ and $\mathrm{DAF}^{\mathrm{hi}}$ GC B cells are located in both the DZ and $\mathrm{LZ}$ of the GC structure. Based on the preferential transcription of AICDA, FOXO1, and BACH2, DAF ${ }^{\text {lo }} \mathrm{GC} \mathrm{B}$ cells in the DZ undergo somatic hypermutation. Moreover, we could also decipher that $D_{A F}{ }^{\text {hi }}$ GC B cells that are located in the LZ comprise cells that express PRDM1 and IRF4, that are associated with PC differentiation. This was corroborated by upregulation of Blimp1 on the protein level. Since transcription of both MYC and PRDM1-1 was elevated among the sorted DAFhi GC B cells, and that expression of these genes are reciprocal for plasma cell development (41), this demonstrated that DAFhi GC B cell population also comprise other subsets of GC B cells. However, our findings suggest that DAF expression, in concert with Blimp1, can be used to identify and further study early differentiation steps for GC-derived PC development.

Our in vitro experiments demonstrated that B cells downregulate surface expression of DAF after BCR engagement alone. This is consistent with our data that show downregulation of DAF on fractions of unswitched activated or memory B cells in circulation and in tonsils. We initially had a hypothesis that DAF would be upregulated on GC B cells that undergo successful selection, but addition of anti-CD40 to mimic interaction with $\mathrm{T}$ cells did only minorly affect DAF expression, and then only in concert with addition of IL-21. Instead, we found that addition of anti-CD40, IL4, or IL21 preferentially led to an upregulation of Ki67 on DAF ${ }^{\text {lo }}$ B cells. Since entry of activated B cells into GC occurs via a T cell dependent checkpoint (42), this could explain why $80-90 \%$ of all GC B cells are DAF ${ }^{\text {lo }}$. However, during the ongoing GC reaction, DAF expression may be regulated largely independent from $\mathrm{T}$ cell-dependent selection. In contrast, $\mathrm{CpG}$ lead to upregulation of Ki67 on both $\mathrm{DAF}^{\text {hi }}$ and $\mathrm{DAF}^{\mathrm{lo}} \mathrm{B}$ cells. It is therefore possible that $\mathrm{T}$ cell-dependent or independent responses have different requirements for modulation of DAF after activation. In this study, we did not find an overall downregulation of the CD55 gene on cells with low surface expression of DAF. This suggests that surface expression of DAF is regulated either by post-translational cleavage or by alternative splicing (43) and studies are on-going to clarify the regulation of DAF.

The complement system is involved in both innate and adaptive immune responses but it also facilitates the removal of dead or dying cells via a non-inflammatory process (44). Products of cleaved complement protein C3, such as $\mathrm{C} 3 \mathrm{~b}$ and C3d, are involved in this process (18). The abundance of C3d in GCs is partially explained by the critical role of C3d for transport of immune complexes into lymphoid follicles and activation of antigen-specific follicular B cells (45). However, data from several early investigations has suggested that GCs may be subject to a local complement cascade, including attachment of complement to cells $(46,47)$. The low DAF expression on GC B cells may explain this, as this would allow for attachment of C3b on cell surfaces (18). Since our flow cytometric data was generated after gating on viable cells (Supplementary Figure S2), they demonstrate that downregulation of DAF had not led to apoptosis, nor lysis via the membrane-attack complex. This latter may be explained by consistent expression of CD59 on GC $B$ cells to hinder the generation of the membrane attack complex by inhibition of C5 convertase (48). It has been described that regulation of complement receptors on GC B cells can influence the threshold for BCR-mediated activation (26), enhance antigen uptake (49), and also facilitate the attachment of these fragments onto B cells (50). We also found that DAF expression was modulated during $\mathrm{B}$ cell hematopoiesis in the bone marrow. This opens up a possibility that regulation of DAF may serve a similar function during B cell development as we show for GC B cells; to prime cells for phagocytosis.

Here, we demonstrate a role of DAF for phagocytosis of GC B cells. While we did not investigate if modulation of DAF could have other beneficial functions for GC B cells, DAF deficient mouse macrophages and dendritic cells have been shown to present antigen more efficiently to $\mathrm{T}$ cells than their DAF expressing counterparts (51). It is therefore possible that the regulation of DAF may serve a dual role where it also allows activated GC B cells to more easily interact with T cells. This would also be in line with previous observations that complement interaction facilitates antigen uptake in mouse B 
cells (49). Hence, studies of cell-specific regulation in small animals will likely be required to fully dissect the impact of DAF on the regulation of humoral immune responses.

Collectively, our data demonstrates a novel role of DAF for regulation of phagocytosis of GC B cells and that modulation of DAF may also play an important role during B cell development. This may explain how B cell homeostasis is maintained at locations where extensive proliferation and apoptosis occurs.

\section{DATA AVAILABILITY STATEMENT}

The datasets presented in this study can be found in online repositories. The names of the repository/repositories and accession number(s) can be found in the article/Supplementary Material.

\section{ETHICS STATEMENT}

The studies involving human participants were reviewed and approved by the Swedish Ethical Review Authority. The patients/ participants provided their written informed consent to participate in this study.

\section{AUTHOR CONTRIBUTIONS}

$\mathrm{AD}$ designed and performed the experiments and wrote the manuscript. JL assisted with the experimental work and critically read the manuscript. AH organized the tonsillectomies and provided expertise in sample processing, and critically read the manuscript. PFK critically analyzed flow cytometric data and provided conceptual suggestions. JM provided conceptual suggestions, assisted with microarray, and critically read the manuscript. CA provided HFRS samples and supervised the project. $\mathrm{JH}$ assisted with bioinformatic analysis and critically read the manuscript. $\mathrm{MH}$ arranged bone marrow sampling and

\section{REFERENCES}

1. Hozumi N, Tonegawa S. Evidence for somatic rearrangement of immunoglobulin genes coding for variable and constant regions. 1976 [classical article]. J Immunol (Baltimore Md 1950) (2004) 173:4260-4.

2. Talmage DW. Allergy and immunology. Annu Rev Med (1957) 8:239-56. doi: 10.1146/annurev.me.08.020157.001323

3. Burnet FM. A modification of Jerne's theory of antibody production using the concept of clonal selection. CA: Cancer J Clin (1976) 26:119-21. doi: 10.3322/ canjclin.26.2.119

4. Muramatsu M, Kinoshita K, Fagarasan S, Yamada S, Shinkai Y, Honjo T. Class switch recombination and hypermutation require activation-induced cytidine deaminase (AID), a potential RNA editing enzyme. Cell (2000) 102:553-63. doi: 10.1016/S0092-8674(00)00078-7

5. McKean D, Huppi K, Bell M, Staudt L, Gerhard W, Weigert M. Generation of antibody diversity in the immune response of $\mathrm{BALB} / \mathrm{c}$ mice to influenza virus hemagglutinin. Proc Natl Acad Sci USA (1984) 81:3180-4. doi: 10.1073/ pnas.81.10.3180

6. Berek C, Berger A, Apel M. Maturation of the immune response in germinal centers. Cell (1991) 67:1121-9. doi: 10.1016/0092-8674(91)90289-B analysis, provided expertise in B cell development, and critically read the manuscript. MF conceived and supervised the study, designed the experiments, and wrote the manuscript.

\section{FUNDING}

The research was supported by intramural funds from Umeå University (AN 2.2.1.2-76-14 and FS 2.1.6-2291-18), Svenska Läkaresällskapet (SLS-787091). The studies of HFRS patients were partially supported by a grant from the National Institutes of Health (U19AI142777-01). The computations were performed using resources provided by SNIC through Uppsala Multidisciplinary Center for Advanced Computational Science (UPPMAX) under Project SNIC 2019/8-143 and uppstore2019072. JH is supported by Vetenskapsrådet \#2016-06598.

\section{ACKNOWLEDGMENTS}

The authors thank Remigius Gröning for commenting on the manuscript; Ellen Ernhill, MD and Anders Erlandsson, MD, for providing the tonsils; Elin Arvidsson for processing and acquisition of the bone marrow samples; and Myriam Martin and Anna Blom at Lunds University for constructive discussions with regard to complement activation. We also would like to thank the Affymetrix core facility at Novum, BEA, Bioinformatics and Expression Analysis, which is supported by the board of research at the Karolinska Institute and the research committee at the Karolinska hospital.

\section{SUPPLEMENTARY MATERIAL}

The Supplementary Material for this article can be found online at: https://www.frontiersin.org/articles/10.3389/fimmu.2020. 599647/full\#supplementary-material

7. Neuberger MS, Lanoue A, Ehrenstein MR, Batista FD, Sale JE, Williams GT. Antibody diversification and selection in the mature B-cell compartment. Cold Spring Harbor Symp Quantitative Biol (1999) 64:211-6. doi: 10.1101/sqb.1999.64.211

8. Victora GD, Nussenzweig MC. Germinal centers. Annu Rev Immunol (2012) 30:429-57. doi: 10.1146/annurev-immunol-020711-075032

9. Green DR, Oguin TH, Martinez J. The clearance of dying cells: table for two. Cell Death Diff (2016) 23:915-26. doi: 10.1038/cdd.2015.172

10. Arandjelovic S, Ravichandran KS. Phagocytosis of apoptotic cells in homeostasis. Nat Immunol (2015) 16:907-17. doi: 10.1038/ni.3253

11. Domen J, Cheshier SH, Weissman IL. The role of apoptosis in the regulation of hematopoietic stem cells: Overexpression of Bcl-2 increases both their number and repopulation potential. J Exp Med (2000) 191:253-64. doi: 10.1084/jem.191.2.253

12. Mayer CT, Gazumyan A, Kara EE, Gitlin AD, Golijanin J, Viant C, et al. The microanatomic segregation of selection by apoptosis in the germinal center. Sci (N Y NY) (2017) 358. doi: 10.1126/science.aao2602

13. Flemming W. Studien über Regeneration der Gewebe. Arch Mikr Anat (1885) 24:50. doi: 10.1007/BF02960374

14. Swartzendruber DC, Congdon CC. Electron microscope observations on tingible body macrophages in mouse spleen. J Cell Biol (1963) 19:641-6. doi: $10.1083 /$ jcb.19.3.641 
15. Smith JP, Burton GF, Tew JG, Szakal AK. Tingible body macrophages in regulation of germinal center reactions. Dev Immunol (1998) 6:285-94. doi: $10.1155 / 1998 / 38923$

16. Sato K, Honda SI, Shibuya A, Shibuya K. Cutting Edge: Identification of Marginal Reticular Cells as Phagocytes of Apoptotic B Cells in Germinal Centers. J Immunol (Baltimore Md 1950) (2018) 200:3691-6. doi: 10.4049/jimmunol.1701293

17. Liu YJ, Joshua DE, Williams GT, Smith CA, Gordon J, MacLennan IC. Mechanism of antigen-driven selection in germinal centres. Nature (1989) 342:929-31. doi: 10.1038/342929a0

18. Martin M, Blom AM. Complement in removal of the dead - balancing inflammation. Immunol Rev (2016) 274:218-32. doi: 10.1111/imr.12462

19. Eldewi DM, Alhabibi AM, El Sayed HME, Mahmoud SAK, El Sadek SM, Gouda RM, et al. Expression levels of complement regulatory proteins (CD35, CD55 and CD59) on peripheral blood cells of patients with chronic kidney disease. Int J Gen Med (2019) 12:343-51. doi: 10.2147/IJGM.S216989

20. Ozen A, Comrie WA, Ardy RC, Domínguez Conde C, Dalgic B, Beser Ö F, et al. CD55 Deficiency, Early-Onset Protein-Losing Enteropathy, and Thrombosis. New Engl J Med (2017) 377:52-61. doi: 10.1056/NEJMoa1615887

21. Takeda J, Miyata T, Kawagoe K, Iida Y, Endo Y, Fujita T, et al. Deficiency of the GPI anchor caused by a somatic mutation of the PIG-A gene in paroxysmal nocturnal hemoglobinuria. Cell (1993) 73:703-11. doi: 10.1016/0092-8674(93)90250-T

22. Richards SJ, Morgan GJ, Hillmen P. Immunophenotypic analysis of B cells in $\mathrm{PNH}$ : insights into the generation of circulating naive and memory B cells. Blood (2000) 96:3522-8. doi: 10.1182/blood.V96.10. 3522.h8003522_3522_3528

23. Schindelin J, Arganda-Carreras I, Frise E, Kaynig V, Longair M, Pietzsch T, et al. Fiji: an open-source platform for biological-image analysis. Nat Methods (2012) 9:676-82. doi: 10.1038/nmeth.2019

24. Jonsson CB, Figueiredo LT, Vapalahti O. A global perspective on hantavirus ecology, epidemiology, and disease. Clin Microbiol Rev (2010) 23:412-41. doi: 10.1128/CMR.00062-09

25. Krautkrämer E, Zeier M. Hantavirus causing hemorrhagic fever with renal syndrome enters from the apical surface and requires decayaccelerating factor (DAF/CD55). J Virol (2008) 82:4257-64. doi: 10.1128/JVI.02210-07

26. Cherukuri A, Cheng PC, Sohn HW, Pierce SK. The CD19/CD21 complex functions to prolong B cell antigen receptor signaling from lipid rafts. Immunity (2001) 14:169-79. doi: 10.1016/S1074-7613(01)00098-X

27. Kischkel FC, Hellbardt S, Behrmann I, Germer M, Pawlita M, Krammer PH, et al. Cytotoxicity-dependent APO-1 (Fas/CD95)-associated proteins form a death-inducing signaling complex (DISC) with the receptor. EMBO J (1995) 14:5579-88. doi: 10.1002/j.1460-2075.1995.tb00245.x

28. Victora GD, Dominguez-Sola D, Holmes AB, Deroubaix S, Dalla-Favera R, Nussenzweig MC. Identification of human germinal center light and dark zone cells and their relationship to human B-cell lymphomas. Blood (2012) 120:2240-8. doi: 10.1182/blood-2012-03-415380

29. Miura Y, Morooka M, Sax N, Roychoudhuri R, Itoh-Nakadai A, Brydun A, et al. Bach2 Promotes B Cell Receptor-Induced Proliferation of B Lymphocytes and Represses Cyclin-Dependent Kinase Inhibitors. J Immunol (Baltimore Md 1950) (2018) 200:2882-93. doi: 10.4049/jimmunol.1601863

30. Muto A, Tashiro S, Nakajima O, Hoshino H, Takahashi S, Sakoda E, et al. The transcriptional programme of antibody class switching involves the repressor Bach2. Nature (2004) 429:566-71. doi: 10.1038/nature02596

31. Inoue T, Shinnakasu R, Ise W, Kawai C, Egawa T, Kurosaki T. The transcription factor Foxol controls germinal center B cell proliferation in response to $\mathrm{T}$ cell help. J Exp Med (2017) 214:1181-98. doi: 10.1084/jem.20161263

32. Turner CA Jr., Mack DH, Davis MM. Blimp-1, a novel zinc finger-containing protein that can drive the maturation of B lymphocytes into immunoglobulinsecreting cells. Cell (1994) 77:297-306. doi: 10.1016/0092-8674(94)90321-2

33. Sciammas R, Davis MM. Modular nature of Blimp-1 in the regulation of gene expression during B cell maturation. J Immunol (Baltimore Md 1950) (2004) 172:5427-40. doi: 10.4049/jimmunol.172.9.5427

34. Calado DP, Sasaki Y, Godinho SA, Pellerin A, Köchert K, Sleckman BP, et al. The cell-cycle regulator c-Myc is essential for the formation and maintenance of germinal centers. Nat Immunol (2012) 13:1092-100. doi: 10.1038/ni.2418

35. Ise W, Kohyama M, Schraml BU, Zhang T, Schwer B, Basu U, et al. The transcription factor BATF controls the global regulators of class-switch recombination in both B cells and T cells. Nat Immunol (2011) 12:536-43. doi: $10.1038 /$ ni.2037

36. Suan D, Kräutler NJ, Maag JLV, Butt D, Bourne K, Hermes JR, et al. CCR6 Defines Memory B Cell Precursors in Mouse and Human Germinal Centers, Revealing Light-Zone Location and Predominant Low Antigen Affinity. Immunity (2017) 47:1142-53.e4. doi: 10.1016/j.immuni.2017.11.022

37. Zou J, Wang C, Ma X, Wang E, Peng G. APOBEC3B, a molecular driver of mutagenesis in human cancers. Cell Biosci (2017) 7:29. doi: 10.1186/s13578017-0156-4

38. Mesin L, Ersching J, Victora GD. Germinal Center B Cell Dynamics. Immunity (2016) 45:471-82. doi: 10.1016/j.immuni.2016.09.001

39. Gaither TA, Vargas I, Inada S, Frank MM. The complement fragment C3d facilitates phagocytosis by monocytes. Immunology (1987) 62:405-11.

40. Theunissen P, Mejstrikova E, Sedek L, van der Sluijs-Gelling AJ, Gaipa G, Bartels $\mathrm{M}$, et al. Standardized flow cytometry for highly sensitive MRD measurements in B-cell acute lymphoblastic leukemia. Blood (2017) 129:347-57. doi: 10.1182/blood-2016-07-726307

41. Lin Y, Wong K, Calame K. Repression of c-myc transcription by Blimp-1, an inducer of terminal B cell differentiation. Sci (N Y NY) (1997) 276:596-9. doi: 10.1126/science.276.5312.596

42. Schwickert TA, Victora GD, Fooksman DR, Kamphorst AO, Mugnier MR, Gitlin $\mathrm{AD}$, et al. A dynamic T cell-limited checkpoint regulates affinity-dependent B cell entry into the germinal center. J Exp Med (2011) 208:1243-52. doi: 10.1084/ jem.20102477

43. Vainer ED, Meir K, Furman M, Semenenko I, Konikoff F, Vainer GW. Characterization of novel CD55 isoforms expression in normal and neoplastic tissues. Tissue Antigens (2013) 82:26-34. doi: 10.1111/tan.12138

44. Kerr JF, Wyllie AH, Currie AR. Apoptosis: a basic biological phenomenon with wide-ranging implications in tissue kinetics. Br J Cancer (1972) 26:23957. doi: 10.1038/bjc.1972.33

45. Carroll MC, Isenman DE. Regulation of humoral immunity by complement. Immunity (2012) 37:199-207. doi: 10.1016/j.immuni.2012.08.002

46. Feucht HE, Jung CM, Gokel MJ, Riethmüller G, Zwirner J, Brase A, et al. Detection of both isotypes of complement C4, C4A and C4B, in normal human glomeruli. Kidney Int (1986) 30:932-6. doi: 10.1038/ ki.1986.275

47. Gajl-Peczalska KJ, Fish AJ, Meuwissen HJ, Frommel D, Good RA. Localization of immunological complexes fixing beta1C (C3) in germinal centers of lymph nodes. J Exp Med (1969) 130:1367-93. doi: 10.1084/jem.130.6.1367

48. Rollins SA, Zhao J, Ninomiya H, Sims PJ. Inhibition of homologous complement by CD59 is mediated by a species-selective recognition conferred through binding to C8 within C5b-8 or C9 within C5b-9. J Immunol (Baltimore Md 1950) (1991) 146:2345-51.

49. Brimnes MK, Hansen BE, Nielsen LK, Dziegiel MH, Nielsen CH. Uptake and presentation of myelin basic protein by normal human B cells. PloS One (2014) 9:e113388. doi: 10.1371/journal.pone.0113388

50. Nielsen CH, Pedersen ML, Marquart HV, Prodinger WM, Leslie RG. The role of complement receptors type 1 (CR1, CD35) and 2 (CR2, CD21) in promoting C3 fragment deposition and membrane attack complex formation on normal peripheral human B cells. Eur J Immunol (2002) 32:1359-67. doi: 10.1002/15214141(200205)32:5<1359::AID-IMMU1359>3.0.CO;2-V

51. Fang C, Miwa T, Song WC. Decay-accelerating factor regulates T-cell immunity in the context of inflammation by influencing costimulatory molecule expression on antigen-presenting cells. Blood (2011) 118:1008-14. doi: 10.1182/blood-2011-04-348474

Conflict of Interest: The authors declare that the research was conducted in the absence of any commercial or financial relationships that could be construed as a potential conflict of interest.

Copyright (c) 2021 Dernstedt, Leidig, Holm, Kerkman, Mjösberg, Ahlm, Henriksson, Hultdin and Forsell. This is an open-access article distributed under the terms of the Creative Commons Attribution License (CC BY). The use, distribution or reproduction in other forums is permitted, provided the original author(s) and the copyright owner(s) are credited and that the original publication in this journal is cited, in accordance with accepted academic practice. No use, distribution or reproduction is permitted which does not comply with these terms. 